\title{
Unity or Secession: perspectives about the 2014 referendum in Scotland
}

\author{
Mariana Mattos de Almeida Cruz ${ }^{1}$
}

\begin{abstract}
RESUMO
Diante da ascensão de movimentos separatistas por todo território Europeu, mais de 2 milhões de escoceses votaram contra a independência de seu país em um referendum histórico em setembro de 2014. 0 presente artigo objetiva fazer uma breve análise dos resultados e implicações do debate sobre a independência da Escócia e procura compreender como movimentos separatistas na Europa estão convergindo em direção a interesses e objetivos regionais, sobretudo relacionados à integração com a União Europeia. Ainda, o trabalho debate as questões do nacionalismo e questiona se há um caminho constitucional para tal independência. A conclusão é de que, considerando o Reino Unido enquanto um modelo de Estado de União, o caso da Escócia pode ser interpretado enquanto um acordo assimétrico. Porém, com os resultados do referendum e as tendências entre os movimentos separatistas, o questionamento sobre a soberania do Parlamento de Westminster foi mostrado improvável até o momento.
\end{abstract}

Palavras-chave: separatismo; Escócia; membro da União Europeia; nacionalismo.

\begin{abstract}
Amidst the arise of separatist movements all over Europe, more than 2 million Scottish voted against independency in an historic referendum on the last September. This article aims to briefly analyze the outcomes and implications of the debate over Scotland's' independence and seeks comprehend how the separatist movements in Europe are converging to regional interests goals, mostly in integrating the European Union. Also, the article debates the issues of nationalism and sovereignty and asks if there is a possible constitutional way to this independence. In conclusion, we find that when we take the United Kingdom (UK) as a union-state model, the Scotland's case can be analyzed as an established an asymmetrical settlement. Yet, with the referendum outcome and the trends across the separatist movements, infringing of the Westminster Parliament's sovereignty is shown to be infeasible until the present moment.
\end{abstract}

Keywords: separatism; Scotland; European Union membership; nationalism.

On the last 19th, more than 2 million Scottish answered "No" to the question: "Should Scotland be an independent country?" The referendum brought by Scotland in the last September closed two years of 'yes' and 'no' parties and confirmed the will of the majority for the unity of the country to the United Kingdom: 55,3\% voted against its independency ${ }^{2}$.

\footnotetext{
${ }^{1}$ Attending Master's Degree in Political Sciences of the Graduated Political Science Department of Federal University of Paraná (UFPR) and researcher of International Relations Research Center (NEPRI).
}

2 Source: http://www.bbc.co.uk/news/events/scotland-decides/results Access: 13/10/14. 
This referendum isn't the only question being debated at the moment in Europe: many others questions concerning issues of separatism, immigration policies and nationalist movement have been on the center of debates in the last decades.

Within this scope, this article aims firstly to analyze and bring to debate two opposite views about Scotland's independence. In addition, and facing this complex scenario, our major questions are: what are the major issues at the independency debate and what would be the possible outcomes of a possible independency of Scotland? How the interests of separatism movements in Europe are converging to regional integration goals, raising questions of nationalism and sovereignty? How the questions of nationalism and sovereignty can be debated in Scotland's case? And, finally, is there a possible constitutional way for independence within the European Union?

\section{Referendum Implications and Arguments}

Although being part of this dynamic yet complex context, the debates over the Scottish independency date for over half century. Since the Treaty of Union, in 1707, incorporation with England did not fundamentally alter their Kirk, their legal system or their local government. Except the manifest disparity of wealth and resources with England, incorporation was initially viewed in Scotland as a partnership. Only from the mid-19th century did state intervention became the norm rather than the exception, and the relationship between Scotland and England has not improved by the decades.

Still in 1954, the Royal Commission of Scottish Affairs reported the "deterioration of the relationship between England and Scotland", followed by the finding of the resurrection of the Scottish economy by that time ${ }^{3}$. Recently, the modern scenario reflects the effects of transnational movements and multi-layered tendencies of the international relations: a growth of the political instability in the UK. Deindustrialization, civic rejection of Thatcherism and the decline of the National Health Service have eroded the social and political capital of British identity 4 .

\footnotetext{
${ }^{3}$ Report of the Royal Comission on Scotish Affairs, 1952-54, Presented to Parliament July 1954.

${ }^{4}$ Source: http://www.bbc.co.uk/history/british/empire_seapower/acts_of_union_01.shtml\#five Access: 13/10/14.
} 
But in these last two years the question of separatism and the British identity crisis has been ah the center of debates, not only for the contemporary and transnational issues in Uk and also Europe (immigration, ecology, nationalism), but also for the possibility of an Independent Scotland represented by the referendum.

In one of the most representative election of UK's history with over 4 million voters registered (4.283.392 voters), $85 \%$ of the electorate turned out to vote, an unprecedented proportion in recent decades. The last UK general election with this rate of participation was in 1951 , with $83,9 \%{ }^{5}$.

Heading the 'Yes' campaign (and SNP leader), First Minister Alex Salmond says the 300-year old Union is no longer fit for purpose, and he assures that the fundamental issue in the referendum is not about nationalism or the economy, but democracy, arguing that the Governments formed at Westminster often do not reflect the majority vote in Scotland.

The Scottish Government also says statistics show and Independent Scotland would be one of the wealthiest countries in the world. Spending per head in Scotland may be higher than the rest of UK, but so is Scotland's tax contribution: in 2013, Scotland produced 245 billion (UK produced 2,5 tri). If Scotland were independent, it would be the 43th position in the global economy. Pro-independence voters also say that Scotland could tailor the welfare system to suit its needs and priorities, instead of being tied into welfare reforms under UK. But key economic and politic issues like the possible currency and the North Sea oil may bring these affirmative into question.

About the currency, the campaign against the independence says there will be no currency union between and independent Scotland and the rest of UK, despite the SNP'S claims this would be 'commom sense' deal arrived at after a 'Yes' vote. Even if there was a currency union, Scotland's economic policy would continued to be decided in London rather than Edinburgh. Furthermore, the three main UK parties - the Conservatives, Labour and the Liberal Democrats - won't seem to agree with this point, and that, whoever is in power would no agree to such a move ${ }^{6}$. Apart from that 'No' campaign also

\footnotetext{
${ }^{5}$ Source: http://www.bbc.co.uk/news/events/scotland-decides/results. Acces: 13/10/14.

6 This position came as the UK Treasury published analysis from its top civil servant, Sir Nicholas Macpherson who outilned several reasons why currency unions were 'fraught with difficulty'.
} 
says that integrations means more economic security: for them, being part of the UK economy means less risk and more opportunities shared within a home market one of the world's largest economies.

The North Sea oil and gas reserves as the tax take from Scotland's share are essential to the Yes campaign. They say earmarking a tenth of revenues - about $£ 1 b n$ a year - could form an oil fund similar to the one operated in Norway, 'creating a $£ 30 \mathrm{bn}$ sovereign wealth pot over a generation'7 Being an important issue for Scotland, and for Britain as well, the Scottish Government predicted $£ 57$ bn tax revenue by 2018.

The counter argument says even if the North Sea has been a British success story, the exploitation would have expiration date: the predictions give 30 to 40 years left of production. Mr. Cameron, Prime Minister of UK, endorse this critic saying that, regarding the oil and gas being non-renewable resources and with expiration date, the UK should focus on back off the industry with the 'broad shoulders' of the UK'. The SNP's opponents also argue they're pinning future hopes on something that's eventually going to run out.

In the security agenda, an independent Scotland in control of its own armed forces would never become involver in 'illegal' wars or invasion of other countries, says Pro-independency movement. They also propose to spend less on defense and focus on maritime capabilities. Another security commitment from SNP is to banish nuclear weapons from Scottish soil. Though critics say moving the submarines to England would make no difference (in fact it could at least cost less to Scotland), but the refusal to house them could represent a political position that could support a decision against renewal of the weapons.

With these implications, outcomes of an independent Scotland would certainly have consequences for the political and social context. Speaking of territory and boundaries, an independency would represent a reduction of $32 \%$ of UKs territory

Macpherson, Nick. Scotland and a currency union. 11 February, 2014. Source: https://www.gov.uk/government/uploads/system/uploads/attachment_data/file/279460/Sir_Nicholas_ Macpherson_-_Scotland_and_a_currency_union.pdf Access in: 13/10/14.

${ }^{7}$ Source: http://www.bbc.com/news/uk-scotland-scotland-politics-26550736 Access: 13/10/14

8 Ibid. 
(Scotland has $78.772 \mathrm{~km} 2)$. In addition, the population would also be reduced in $8 \%(5,3$ million), meaning $8 \%$ less electorate.

Nonetheless, between the 'Yes' and 'No' arguments, the issue that has been in the center of the debates is the assessment of the influence of an independent Scotland in the world. We narrow our analysis to this question to: how would be the Scotland's relationship with the European Union?

\section{The European Union relationship}

The question of Scottish independence and its relationship with European Union has been heavily debated in the United Kingdom, since one claim against its independence being that some European countries might not recognize its independence and would therefore block Scotland's membership of the European Union.

Though supporters of independence insist that membership would be 'automatic', the counter argument suggests that there's no automatic process to become a member of European Union. In fact, the 'No' campaign members support their position mentioning cases like Kosovo or South Sudan (Ker-Linsay, 2012).

When Kosovo declared its independence from Serbia in 2008, it was quickly recognized by most of the members of EU, except by Cyprus, Greece, Romania, Slovakia and Spain. This led to suggestions that these countries may also refuse to accept Scotland's independence.

But the refuse of a membership is very unlikely for these reasons (Ker-Linsay, 2012): the problem in Kosovo wasn't an issue of secession, but the unilateral decision that has been taken. Also, if a territory became independent with the consent of all the parties concerned, there is little reason to believe these countries will oppose the move.

The strongest evidence to support this view is the reaction of these five countries to the independence of the South Sudan in 2011, which was collectively recognized by EU a few hours after the movement (Ker-Lindsay, 2012).

\footnotetext{
9 Source: http://www.ibtimes.co.uk/scottish-independence-snp-claims-scotland-will-have-automatic-eumembership-1464801 Access: 13/09/14.
} 
In fact the only EU member that could potentially pose a problem is Spain (KerLindsay, 2012). Recently, a recent claim by the British government that said Spain would reject the membership from Scotland was denied by the Spanish foreign minister. Also, a strong evidence that Spain would not be obstructive is Spain's decision to recognize South Sudan as well as Croatia, Slovenia, Bosnia, Montenegro, Macedonia, Slovakia, Moldova and the Czech Republic.

Finally, this question is also relevant since the UK has a permanent place on the United Nations Security Council and is one of the largest member states in the European Union.

\section{Secession and Sovereignty}

Recent events in a number of European States have pushed the issue of secession up the political agenda, in a general context they bring into question issues about the sovereignty of states and the rise of nationalism movements in the context of an integrating Europe.

The date of the referendum in Scotland has been selected with consideration to mark the $700^{\text {th }}$ anniversary of the Battle of Bannickburn, a legendary victory in the First War of Scottish Independence. But, with just two days to go before Scotland votes on its independence, separatist movements across Europe have become energized by the real possibility that the United Kingdom could be about to split. Europe is awash with a number of pro-independence entities, but those in Spain, Belgium and Italy have seized the moment to reignite their own agendas ${ }^{10}$.

In neither case, however, does there seem to be a wish to combine independence with an exit from the European Union. The Scottish National Party (SNP), in particular, have long campaigned on the slogan 'Independence in Europe', seeking to persuade voters that they can have the best of both worlds: Scottish independence and EU membership.

\footnotetext{
10 Source: http://www.ibtimes.com/scottish-independence-vote-reignites-separatists-across-europe1689523 Access: 13/10/14
} 
How to explain then the Scottish separatist movement (mostly SNP) being related to an apparently paradoxical interest in integrate EU? And how works the concept of sovereignty in a globalized context?

First, surpassing the image of an integrating Europe that has vanquished nationalism, the acts of separatism movements are not only enduring under conditions of integration but also adapting to the challenges of integration and developing new strategies to take advantage of their situation in, and access to, EU institutions (Laible, 2012).

These new strategies resituated the drive for independence in the context of an integrating Europe: there was a trend across the member states of the European Community where major separatist and autonomist parties in Wales, Catalonia, the Basque territory, Flanders, northern Italy had begun to articulate a vision of selfgovernment that promoted a strong, positive role for their perspective nations "in Europe" (Laible, 2012). It has begun with SNP in 1988, when they voted for a new election theme 'Independence in Europe'.

Initially, nationalist parties had commonly called for the establishment of fully sovereign and at times even economically autarchic new states. However, by the late 1980s, many were claiming that success, if not very survival, of any independent state they might seek to establish would be inexorably linked to its situation within an integrating European polity.

The idea of integration in a separatist movements seem initially paradoxical: the desire to secure sovereign authority and then immediately to surrender it to a national or multinational European institution appears to undermine the very premise of nationalism. Separatists could understand "independence" as the creation of new sovereign states outside the borders of an integrating Europe. But numerous parties have retooled their strategies to embrace Europe at precisely the historical juncture at which state sovereignty appears to have been dealt its more severe blow (Laible, 2012).

The explanation, for Laible (2012), is that "The EU sustains the importance of statehood, and therefore separatism, and creates new forms of political capital that nationalists can employ to support their claims for self-government" (Laible, 2012, p.3.) 
Statehood is here understood not as the intrinsic end of nationalist politics but as means for nationalists to achieve legitimacy and authority, thus opening the possibility that statehood may remain valuable to separatists even under conditions of highly compromised sovereignty that exist in the EU.

In conclusion, the State continues to be a central issue in separatist politics, but the meaning of statehood for separatist has changed: while capturing an independent state was once the means to claim full sovereignty over a specified territory, this is no longer possible in a world where state sovereignty has been compromised by regional and global integration (Laible, 2012). However, achieving independence still represents the optimal means for nationalists to maximize sovereignty in the EU.

\section{Globalization, welfare and nationalism}

The complex international scenario nowadays and the emergence of identity politics, including territorial politics, have undermined the welfare state by compromising the common culture and sense of national citizenship which made welfare states possible (Wolfe and Klausen, 1997). However, it is precisely in multinational states that the protection and security offered by systems of state welfare may contribute to promoting the idea of a social nation throughout the state territory, which can emphasize a sense of identification with a cultural-historical nation within the state. Moreover, in the face of a territorial challenge to the integrity of the state, the economic and social security guaranteed by the welfare state could be contrasted with the insecurity of enhanced sub-state autonomy or secession (La Chapelle \& Paquin, 2005).

From this perspective, the relation s of globalization and the trend of sub-state regionalism and nationalism have become more comprehensible and yet more ambiguous: globalization can limit the national state's autonomy and capacity to accommodate territorial minorities within existing political and institutional structures, while it can offer opportunities for sub-state nations to influence the international arena (LaChapelle \& Paquin, 2005). 
Nationalism can be defined a political principle that demands that the unit of governance and the nation should be congruent. It replaces the principle of dynastic sovereignty on which agrarian empires were based (Lars-Erik, Andreas Wimmes, Brian Min, 2010). Hence, whereas the unit of governance is usually understood to be the sovereign state, the nation is imagined as a community of common origin and shared historical destiny.

Thus, a common national identity and territorial solidarity within state welfare regimes can legitimize redistributive policies and can in return be reinforced by the symbolism and services of welfare states that recognized social rights and met social and economic needs (McEwen, 2001). Nonetheless, when such rights are denied and services withdrawn in the face of neoliberalism and globalization, social and national solidarity is weakened, contributing in some cases to increased demands for territorial autonomy and the sub-state level. T

Facing this scenario, even in the UK we can found asymmetries in terms of politics and in the centralized government. Underlying these constitutional differences is an asymmetry in identity and self-representation (Keating \& Elcock, 2013). In the minority nations, there has long been a dual identity issue for the citizens: in Scotland, the citizens can be both Scottish and British. For the citizens it can be both competing and incompatible identities or compatible and representative ones. The asymmetry arises when there is no corresponding intermediary identity for the majority of the populations.

Considering the UK union-state model (Rokkan and Urwin, 1983), these asymmetries present fundamental problems for the constitution. The model is defined here as a state without a formal federal division of powers but in which parts of the territory have been incorporated by treaty and agreement; while administrative standardization prevails over most of the territory, the union structure entails the survival in some areas of variations based on union rights and infrastructures (Rokkan an Urwin, 1983, p.181)

Asymmetric decentralization in UK can be analyzed based on the theory that the multination state is not a homogeneous whole, to be divided according to administrative convenience and undifferentiated principles of representation, but a union of territories 
brought together in a pact (Keating \& Elcock, 2013). Yet, opponents present an argument from an universalist point of view which states that minorities should be prepare to dissolve their special status into a homogeneous whole, which would not benefit any group in particular. Since dissolving particular identities into a common whole would define the whole by the values of the majority, this argument could be easily used by the majority against the minorities.

The critic's approach against asymmetry focus on issues of sovereignty; autonomy; equality of rights; issues of representation; issues of influence and access; and issues of fiscal equity and economic competition. There is also speculative argument to the effect that asymmetrical arrangements are inherently unstable and will therefore lead eventually to the secession of the territory (Keating \& Elcock, 2013).

The union principle provides a different intellectual frame to approach the issue of asymmetry, at least in relation to Scotland. It does not, however, provide the solution, nor does it resolve the specific issues raised by critics.

Concerning the issue of sovereignty, there is a common British argument that is impossible to divide sovereignty, centralized in Parliament. Yet, the principle of parliament sovereignty was never recognized by Scottish constitutional practice before the Union of 1707. Although considered as many scholars as unresolved and somewhat academic, the sovereignty issue may be possible to be fudged into practice, since Great Britain has done this for nearly 300 yeas, and European integration has emptied it of much of its old meaning. Yet, underlying the debate, is an important question about nationality and legitimacy.

A clause in the Labours Government's Scotland Act (1978) declared that nothing in it detracted from the sovereignty of the Westminster Parliament as defeated by an unholy alliance of unionists and Scottish nationalists. Also, the very language of union and pactism was, ironically, used by the British Conservatives in a paper opposing constitutional change, when John Major (1992) stated that 'no nation can be kept in a union against its will'. The Campaign for a Scottish Assembly's Claim of Roght (CSA, 1988) insisted that sovereignty belonged to the Scottish people, who had the right to negotiate their place in the union. 
Labour, on the other hand, has been pursuing and contradictory track: after going on with the Scottish Constitutional Convention's assertions on Scottish sovereignty, it has now retreated to its 1970 s position, insisting that nothing in the scheme will affect the sovereignty of the Westminster Parliament. In this case, 'the UK Parliament would remain sovereign, but the essence of devolution is that for certain powers would be passed on to an elected Scottish parliament. That is what devolution means, that Westminster politicians decide that they should exercise some of their powers relating to Scottish affairs by devolving them to a parliament set up by them for that purpose' (Geroge Roberstson, 1996).

In conclusion, UK would remain to decide on the appropriate institutions for each part of its territory, and the Westminster Parliament would still have ultimate control. Although, it legitimize an asymmetrical settlement when the constituent parts have not altogether given up their rights, and implies a settlement by negotiation and not imposed.

\section{Is there a constitutional path to independence?}

In the context of a statehood, is there a constitutional path to independence within the European Union? In fact, addressing the European Parliament in the context of contemporary concern about extreme right participation in the government in Austria, President Prod stated in plain terms that there is no provision in the Treaty on European Union for the departure or expulsion of a state. All that is provided for is a suspension of rights of membership in case of proven violation on human rights or other fundamental value of the EU (using the criteria process stipulated in Articles 6 and 7). There is no provision for unilateral secession from the treaty, nor any for compulsory expulsion (MacCornick, 2000).

Supposing Scotland in its present condition as a devolved part of the United Kingdom sought to leave the European Union, the UK could not unilaterally legislate for Scottish independence in such terms as unilaterally to remove the relevant territory from EU jurisdiction. 
Whenever the Treaties, as the Constitutional Chart of the EU, have come to be in force in respect of a state, extending to every part of its territory, they remain in force for the whole territory or territories in question, until such time as any variation of this or derogation from it is determined by an Intergovernmental Conference and enshrined in an appropriate treaty.

Regarding the conditions for achieving membership in the case of Scotland, it is not necessary for a state to have demonstrated a commitment to democratic selfgovernment under the rule of law and with due respect for human rights and the rights of minorities. It is also necessary for a state to have shown itself capable of accommodating the 'acquis communautaire' in its law. Finally, it must have established a successfully functioning market economy. In conclusion, the existence of a constitutional path to independence is clear, from both the points of view of Scots law and English lawn (MacCornick, 2000).

\section{Scotland votes 'No': What happens now?}

After 2.001.926 million voters said Scotland should not be an independent country, amid all the reaction and the talk of further reform, the primary outcome is that Scotland stays in the Union. For now, that means it will continue to form an integral part of the UK - but for Scottish devolution, the focus will now be on how the UK government delivers its promise of more powers for the Scottish parliament.

The three biggest UK- wide political parties - The Conservatives, Labour and the Liberal Democrats - agreed that further devolution of powers to Holyrood must take place. During the referendum campaign, the parties signed a pledge ${ }^{11}$ to devolve more powers to Scotland, if Scots rejected independence.

After the results, the Scottish government called for a wide range of powers to be transferred to Scotland, including control over income tax, national insurance, corporation tax, capital gains tax, fuel duty, air passenger duty and inheritance tax. Following the "No" vote, Mr. Salmond announced his resignation as SNP12. As we

\footnotetext{
${ }^{11}$ Source: http://www.bbc.com/news/uk-scotland-scotland-politics-29213418 Access: 13/10/14 12 Ibid.
} 
debated, sovereignty was part of the independence's discussion over the years in Scotland's politics, but the conclusion is that it has never been really threatened by separatist movements. The UK, as founded in 1707, subject to considerable subsequent amendment, remains.

On the other hand, the devolution is discussed and it represents a possible or at least one tangible arrangement between the Parliament and the Scottish people. When we consider the UK as a union state model (with different territories brought together by a pact) with all its inherent contradictions regarding issues of nationalism and identities, we identify that Scotland's case as an asymmetrical settlement, when the terms are negotiated and not imposed. This situation can also be evidenced with the referendum outcome: the population itself voted for the union. We can observe that the will of the majority (even if they're 53\%) is to remain in the Union.

Furthermore, the trend of the interest in Europe's integration from the separatist movement is another evidence that Westminster sovereignty is not being questioned so far. The rearticulated vision of separatists of self-government that promotes a strong, positive role for their perspective nations 'in Europe', reinforces the 'Statehood' as means for nationalists to achieve legitimacy and authority,

In conclusion, among separatist movements in Europe, the Scotland referendum case still reverberates and the independence will continue to be debated in Scottish politics. The 'No' answer from the Scottish reflects the trends of integration even among the separatists, and lead the debate towards the policies of devolution instead of secession. Yet, questions of sovereignty and nationalism will continue to be raised, even more if we consider that the EU has endorsed the importance of statehood in creating new forms of political capital to support new concepts of separatism.

\section{References}

BRANCATI, D. (2009). Peace by design. New York, NY: Oxford University Press.

BUNCE, V. (1999). Subversive institutions: The design and the collapse of socialismand the state. New York, NY: Cambridge University Press. 
DIAMOND, L. (1999). Developing democracy: Toward consolidation. Baltimore, MD: Johns Hopkins University Press.

HALE, H. E. (2008a). The double-edged sword of ethnofederalism: Ukraine and theUSSR in comparative perspective. Comparative Politics, 40, 293-312

HECHTER, M. (2000).Containing nationalism. New York, NY: Oxford UniversityPress.

KEATING, M. and Elcock, H. (2013). Financial Arrangements for UK Devolution. In Remaking the Union (pp30-60). Abingdon, Oxon: Routledge, 2013.

KER-LINDSAY, James. An independent Scotland would face little European opposition to membership of the European Union, 2012. Available at: <<http://eprints.lse.ac.uk/43746/1/_Libfile_repository_Content_LSE\%20Politics\% 20and\%20Policy\%20Blog_March\%202012\%20to\%20be\%20added_blogs.lse.ac.ukAn_independent_Scotland_would_face_little_European_opposition_to_membership_ of_the_European_Union.pdf $>>$ Access: 21/09/2014.

LAIBLE, Janet. Separatism and Sovereignty in the New Europe: party politics and the meanings of Statehood in a supra national context. New York: Palgrave Macmillian, 2008.

LARS-ERIK CEDERMAN, Andreas Wimmer, and Brian Min. 2010. "Why Do Ethnic Groups Rebel? New Data and Analysis". World Politics 62(1):87-119, 2010

MACCORMICK, N. Is there a constitutional path to Scottish independence? Parliam Aff (2000) 53 (4): 721-736 doi:10.1093/pa/53.4.721

MCEWEN, N. "State welfare nationalism: the territorial impact of welfare state development in Scotland and Quebec", unpublished thesis, University of Sheffield, 2001.

MICHAEL HECHTER (1979). On Separatism and Ethnicity: A Response to Sloan's 'Ethnicity or Imperialism?'. Comparative Studies in Society and History, 21, pp 126129. doi:10.1017/S0010417500012688.

PAQUIN, S. and LACHAPELLE, G. Mastering Globalization: New Sub-States' Governance and Strategies. Routledge, 2005. 
ROKKAN, Urwin. Economy, Territory, Identity, Politics of West European Peripheries. London: Sage, 1983.

SIROKY, D. and CUFFE, J. 'Lost Autonomy, Nationalism and Separatism', Comparative Political Studies, doi: 10.1177/0010414013516927, 2014. 